\title{
A Proof-of-Concept Portable Water Purification Device Obtained from PET Bottles and a Magnetite-Carbon Nanocomposite
}

\author{
Elisabetta Gaita ${ }^{1}$, Claudio Evangelisti ${ }^{2}$ (D) and Guido Panzarasa ${ }^{3, *,+}$ (D) \\ 1 Liceo Scientifico “Ascanio Sobrero”, via Candiani d'Olivola 19, 15033 Casale Monferrato, Italy; \\ gaita.eli@gmail.com \\ 2 Istituto di Scienze e Tecnologie Molecolari, Consiglio Nazionale delle Ricerche, c/o Polo Scientifico e \\ Tecnologico via G. Fantoli 16/15, 20138 Milano, Italy; claudio.evangelisti@istm.cnr.it \\ 3 Department of Polymer Science and Engineering, Montanuniversität, Otto-GlöckelStrasse 8, \\ 8700 Leoben, Austria \\ * Correspondence: gp4779@gmail.com; Tel.: +41-079-679-1994 \\ + Present address: Laboratory for Soft and Living Materials, Department of Materials, ETH Zürich, \\ Vladimir-Prelog-Weg 5, 8093 Zürich, Switzerland.
}

Received: 18 March 2018; Accepted: 28 June 2018; Published: 1 July 2018

\begin{abstract}
Widespread access to potable water is still far from being granted to populations of developing countries, especially in rural zones. For this reason, the development of easy-to-make, easy-to-use water purification devices is a topic of great social and economic importance. Poly(ethylene terephthalate) (PET) bottles are available worldwide, even in the remotest and poorest countries, as testified by the increasingly common practice of re-using bottles for solar water disinfection (SODIS). Here, we demonstrate how PET bottles could be re-used as a proof-of-concept water purification system. In this way, virtually the same bottle could be used first for SODIS and then for removing chemical contaminants. In the proposed approach, the bottles are treated with ethylenediamine to introduce amine groups, which are subsequently protonated with dilute acid. These functional groups allow the stable adsorption of a magnetite-activated carbon nanocomposite, which is prepared by a simple coprecipitation protocol. The efficiency of the nanocomposite and of the resulting prototype to remove model inorganic and organic pollutants (hexavalent chromium, industrial dyes) from water has been demonstrated. The proposed purification device is easy, cheap, and effective, all factors which could promote its use in developing and rural countries.
\end{abstract}

Keywords: PET bottles; magnetite; activated carbon; nanocomposites; water purification; water pollutants; hexavalent chromium; methylene blue; methyl orange

\section{Introduction}

Access to potable water should be an undisputable right for people all over the world. Water pollution, however, due to both natural and anthropic reasons, constitutes a serious health problem in poor and developing countries [1]. This is especially true for people living in highly industrialized regions of developing countries such as China and India, where the effluents from, for example, textile dying plants are often inadequately treated before their release in the environment. For this reason, empowering individuals and small communities with easy-to-make portable water purification devices is one solution to improve the quality of water and thus of peoples' lives [2].

In the present work, we describe the preparation of a nanocomposite that combines the reducing and magnetic properties of magnetite with the high adsorbing capacity of activated carbon [3-6]. After evaluating the efficiency of this nanocomposite for the removal of model inorganic and organic 
pollutants, we demonstrate how to attach it to the internal walls of poly(ethylene terephthalate) (PET) water bottles to develop a proof-of-concept portable water purification device. PET bottles were chosen as a substrate thanks to their wide availability (PET being the most favorable packaging material world-wide for beverages [7]) and possibility of easy chemical modification. It is important to clarify that since the recycling of PET bottles usually implies their destruction in order to obtain pellets to be molded or monomers to be polymerized [8], here we prefer the term "re-use".

Considering the huge yearly worldwide consumption of PET bottles (for example, around 573,000 tons in Japan in 2007 [9] and nearly 100,000 tons in China in 2012 [10]) and that some developing countries (especially India) have already well-established recycling industries, the availability of enough re-usable PET bottles can be easily taken for granted. This has already been shown by the success of solar water disinfection (SODIS) practices [11-13], in which PET bottles filled with water are exposed to sunlight for reasonably long times in order to allow the combined effect of UV radiation and heat to inactivate pathogens and reduce microbiological contamination [14-17]. SODIS, however, is ineffective for the removal of chemical pollutants, which is the scope of our proof-of-concept system.

The use of nanomaterials to help solve environmental problems has been increasingly receiving attention, for example, to accelerate sewage's coagulation, remove radionuclides, for oil spill remediation, and for the adsorption of organic dyes [18-24]. In this context, magnetic materials, and especially magnetite $\mathrm{Fe}_{3} \mathrm{O}_{4}$, occupy a special place. Magnetite nanoparticles can be produced in a wide range of sizes and shapes by means of techniques with different degrees of sophistication $[25,26]$.

Thanks to their magnetic properties, magnetite nanoparticles find applications in several different areas such as targeted drug delivery [27], cancer diagnosis and treatment (hyperthermia) [28,29], as contrasting agents in magnetic resonance imaging (MRI) [30], for detoxification of biological fluids (e.g., blood) [31], and in cell separation [32]. Magnetic composites can be conveniently prepared by adding different adsorbents to the mixture of iron salts before co-precipitation. They combine the adsorption properties of adsorbents, such as activated carbon or clays, with the magnetic properties of iron oxides. This makes them efficient at removing many different types of contaminants, including both inorganic and organic, from water. Moreover, after use they can be separated by the aid of a magnet, thus allowing for easy collection and recycling of the spent adsorbent (Figure 1) [33,34].

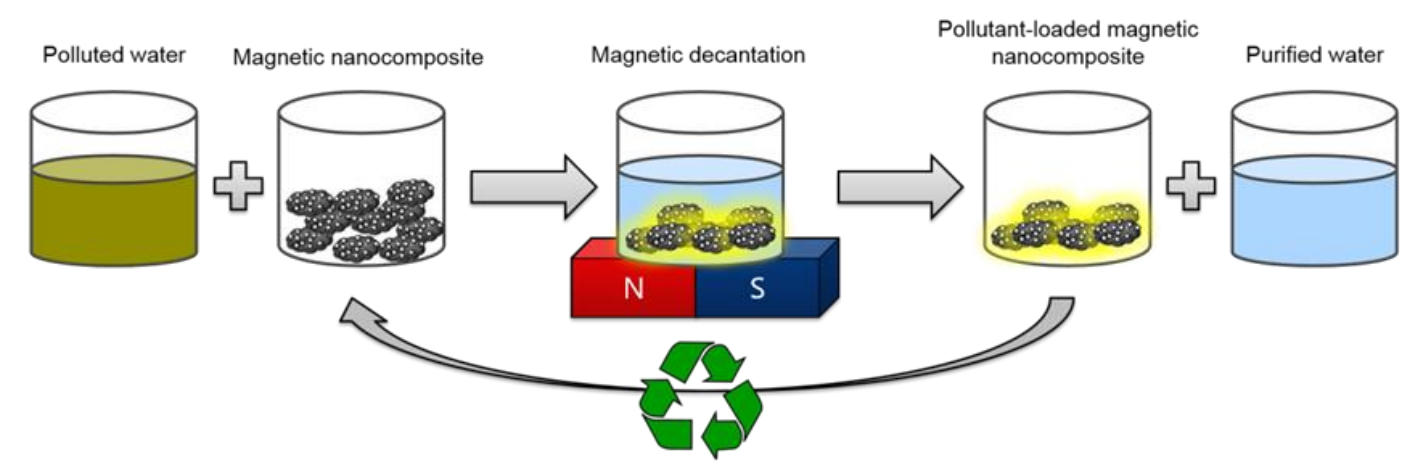

Figure 1. Schematic representation of the preparation and use of magnetic nanocomposites for water purification.

It is important to note here that the interest in magnetite for environmental remediation purposes goes beyond its magnetic properties, since its redox potential $\left(\mathrm{E}_{0}=0.66 \mathrm{~V}\right.$, corresponding to the semi-reaction $\mathrm{Fe}^{2+} \rightarrow \mathrm{Fe}^{3+}+\mathrm{e}^{-}$) is favorable for the deactivation of pollutants, such as the reduction of carcinogenic hexavalent chromium $\mathrm{Cr}^{6+}$ to harmless $\mathrm{Cr}^{3+}[35,36]$. In the present study, hexavalent chromium, methyl orange, and methylene blue were chosen as model pollutants because of their industrial relevance, solubility in water, and characteristic UV-vis absorption. Hexavalent chromium is a known carcinogenic pollutant, while methyl orange and methylene blue are common organic dyes [37]. 


\section{Results and Discussion}

\subsection{Synthesis and Characterization of Magnetite Nanoparticles and of the Activated} Carbon-Magnetite Nanocomposite

Magnetite nanoparticles can be conveniently prepared through co-precipitation of iron (II) and iron(III) salts, typically chlorides, with a 1:2 Fe(II)/Fe(III) molar ratio. Upon addition of an excess of a base, typically ammonium hydroxide, magnetite precipitates as a black fine powder that is readily attracted by a magnet [38]. The overall reaction may be written as follows (Equation (1)):

$$
2 \mathrm{FeCl}_{3}+\mathrm{FeCl}_{2}+8 \mathrm{NH}_{4} \mathrm{OH} \rightarrow \mathrm{Fe}_{3} \mathrm{O}_{4}(\mathrm{~s})+4 \mathrm{H}_{2} \mathrm{O}+8 \mathrm{NH}_{4} \mathrm{Cl}
$$

If the iron salts solution is mixed together with other materials having some affinity for the iron cations or for magnetite itself, in this case, a fine suspension of activated carbon, nanocomposites can easily be obtained upon the addition of the precipitating agent.

The obtained nanoparticles were analyzed by means of zeta potential analysis, X-ray powder diffraction (XRPD), and transmission electron microscopy (TEM). Zeta potential analysis revealed that the magnetite particles were negatively charged $(-20 \pm 0.5 \mathrm{mV}$, in perfect agreement with literature results [39]). As can be seen in Figure 2A,B, magnetite nanoparticles with an average size of $10 \pm 2 \mathrm{~nm}$ were obtained, whose crystallinity was suggested by the Fourier transform of the electron microscopy images (Figure 2B, inset) and further confirmed by XRPD (Figure S1). This latter technique showed the reflexes typical of magnetite with scattering domains of $8 \pm 1 \mathrm{~nm}$, which is in accordance with the TEM results. For the magnetite-carbon nanocomposite, the TEM images (Figure 2C,D) showed the magnetite particles together with an amorphous matrix of carbon, demonstrating the successful preparation of the nanocomposite.
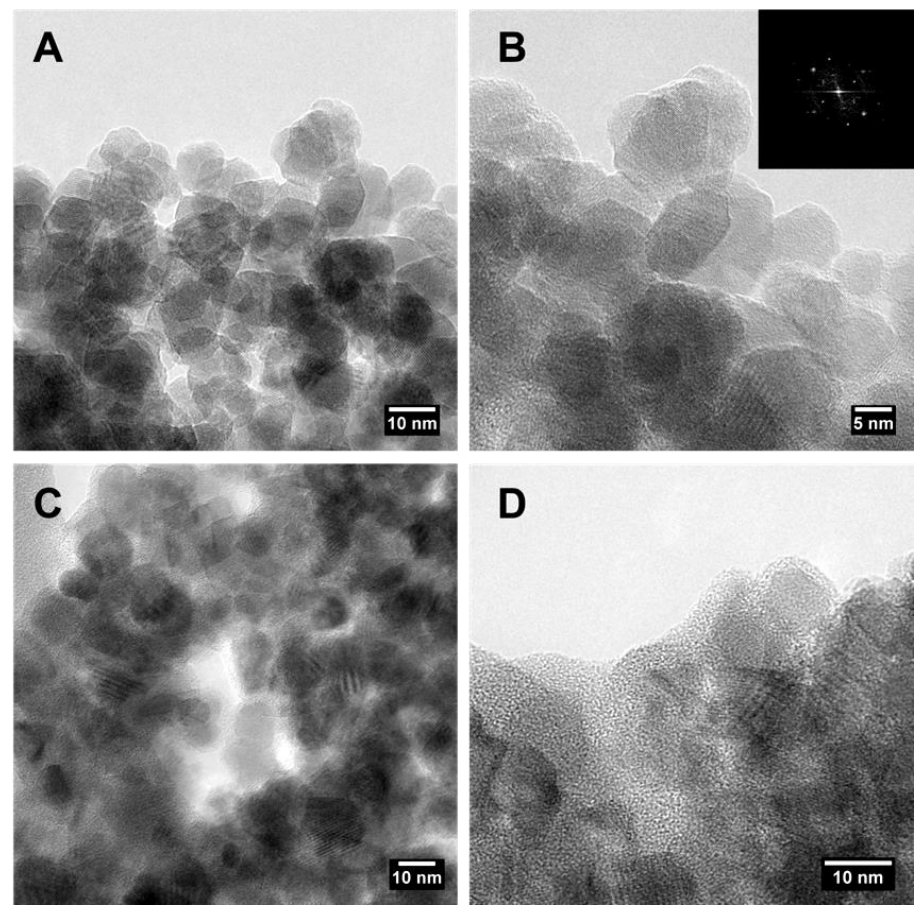

Figure 2. Representative transmission electron microscopy (TEM) micrographs of the obtained particles: (A,B) magnetite nanoparticles; (C,D) magnetite-activated carbon nanocomposite. The inset in (B) shows the Fourier transform of the electron diffraction pattern, demonstrating the crystallinity of magnetite nanoparticles. 


\subsection{Removal Efficiency for Hexavalent Chromium}

Hexavalent chromium $\mathrm{Cr}^{6+}$ is a well-known water pollutant with carcinogenic properties [40]. Its deactivation can occur by removal (e.g., adsorption) or reduction to trivalent chromium $\mathrm{Cr}^{3+}$, which is harmless. The chromate anion $\mathrm{CrO}_{4}{ }^{2-}$ has a typical light absorption at $435 \mathrm{~nm}$, which is absent in species containing $\mathrm{Cr}^{3+}$. It is thus possible to determine and compare the efficacy for $\mathrm{Cr}^{6+}$ reduction of magnetite nanoparticles and of the magnetite-carbon nanocomposite by measuring the absorption at $435 \mathrm{~nm}$ before and after treatment. The results are summarized in Figure 3A. The concentration of $\mathrm{Cr}^{6+}$ in the "Reference" solution was dramatically reduced (of about $64 \%$ and $92 \%$, respectively) after the treatment with magnetite nanoparticles ("Magnetite") and with the magnetite-carbon nanocomposite ("Magnetite-carbon"). It is interesting to compare these results with those obtained with atomic absorption spectroscopy, since UV-vis spectroscopy measures the reducing efficiency while the atomic absorption measures the efficiency of removal by absorption. This enabled us to determine the concentration of overall chromium in the samples regardless of its chemical nature (i.e., without making distinction between $\mathrm{Cr}^{6+}$ and $\mathrm{Cr}^{3+}$ ). The results are shown in Figure 3B. The removal efficiency of magnetite alone is not relevant, as expected. In contrast, the percentage of chromium removed by the magnetite-carbon nanocomposite is around $94 \%$.
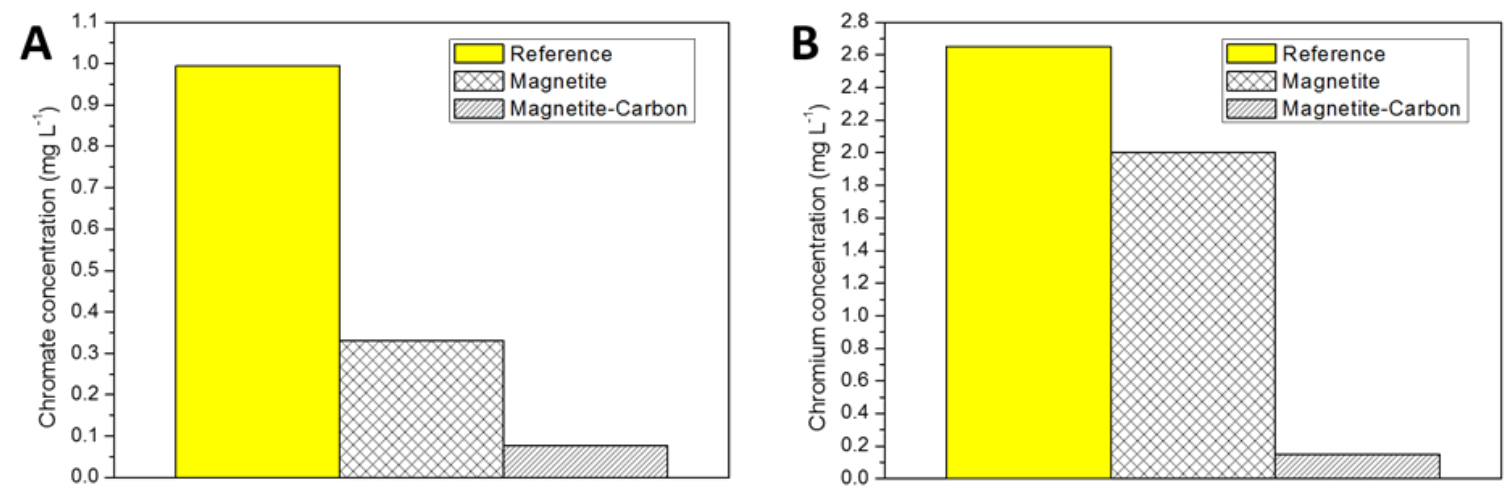

Figure 3. Comparison of the efficiency of magnetite and the magnetite-activated carbon nanocomposite for the removal of hexavalent chromium, with results obtained from (A) UV-visible spectrophotometry (UV-vis) and (B) atomic absorption spectroscopy (AAS).

\subsection{Removal Efficiency for Industrial Dyes}

Methyl orange in its neutral form has a negative charge due to the presence of a sulfonate moiety. However, at acid $\mathrm{pH}$, the tertiary amino group can be protonated, which generates a positive charge. The molecule of methylene blue is naturally positively charged. Since the surface of magnetite is negatively charged, it is possible to make a first comparison of adsorbent efficiency based on the pollutant electric charge. However, magnetite alone was found to be ineffective for the removal of organic dyes. Adsorption of chemical species on activated carbon is usually supposed to occur due to electrostatic (between carboxylic acid groups on carbon and positively charged species) and hydrophobic interactions (such as $\pi-\pi$, in the case of aromatic compounds) [41]. As shown in Figure S3, the color intensity of the dyes' solutions strongly decreases after the treatment with the magnetite-carbon nanocomposite. This observation is confirmed by the absorbance values reported in Figure 4, which show that the magnetite-carbon nanocomposite is very effective in removing the tested organic pollutants. These findings were confirmed by a reproducibility test (Figure S4), which also showed that the magnetite particles alone were not effective in removing the dyes. Furthermore, the data suggested that positively charged molecules are removed more efficiently. The magnetite-carbon nanocomposite was thus chosen for the development of the water purification device. 


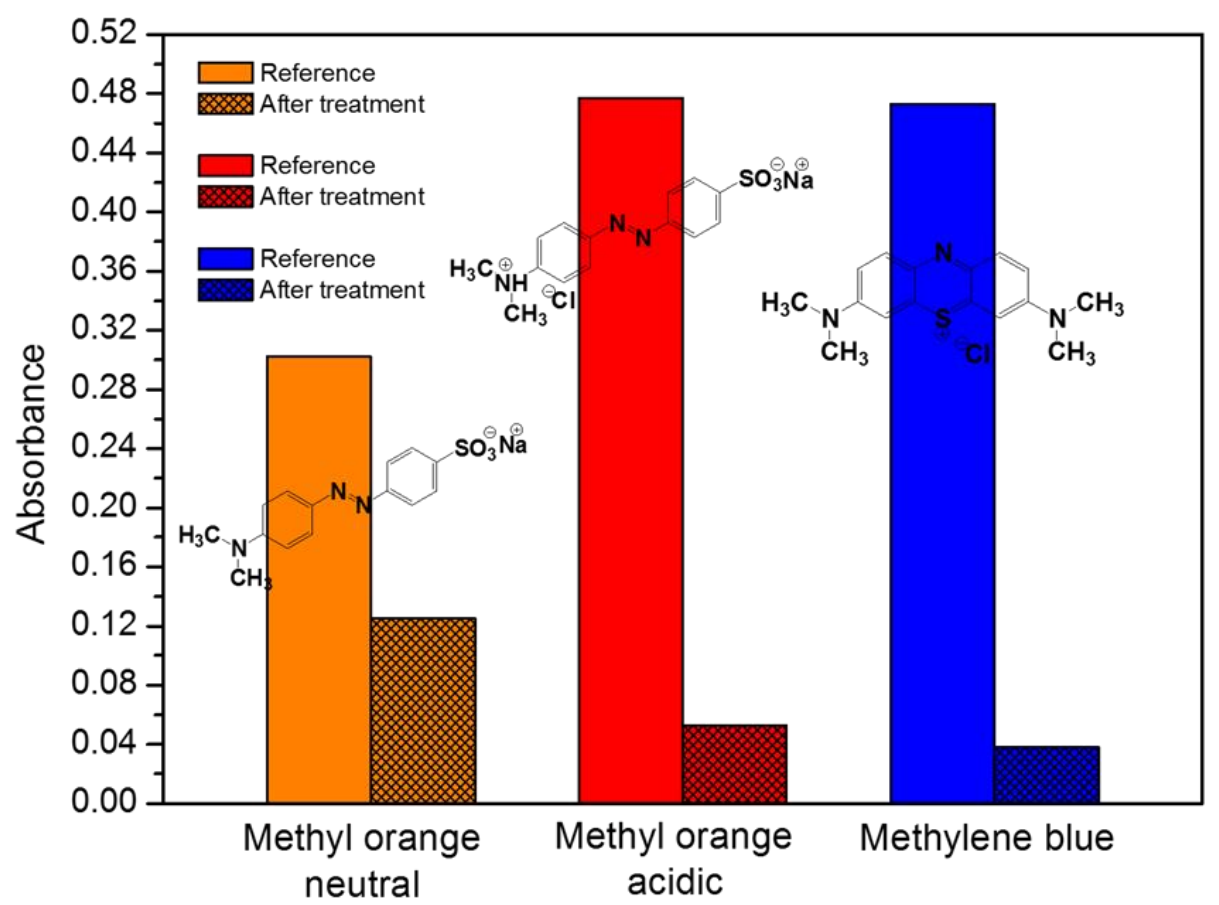

Figure 4. Evaluation of the efficiency of the magnetite-carbon nanocomposite for the removal of organic dyes.

\subsection{Development of a Proof-of-Concept Portable Water Purification Device}

Water bottles are conveniently made of poly(ethylene terephthalate) (PET), a hydrophobic plastic. The main benefits of using this kind of polyester are, from an industrial point of view, low weight, mechanical stability, and recyclability [42]. From a surface chemistry point of view, however, it also allows aminolysis reaction to occur when treated with amines, such as ethylenediamine. It is important to note here that other amines, including polymeric amines such as branched poly(ethyleneimine) (a common industrial polymer) could be used as well [43]. Thanks to this process, which is typically used for bioconjugation purposes, amine groups were generated on the PET bottle internal surface, making it hydrophilic [43-45]. Compared to the original literature procedure, we used ethanol instead of toxic methanol. Noteworthy, the aminolysis treatment did not affect the transparency of the bottle. The amine groups were easily protonated by acid treatment, which makes them positively charged and capable of attracting the negatively charged nanocomposite particles thanks to electrostatic forces (Figure 5). As a demonstration of successful aminolysis reaction, particles were not found to adhere on untreated bottles.

The efficiency of the prototype was tested with acidic methyl orange and potassium chromate. The bottles modified with the magnetite-carbon nanocomposite were filled with either a $0.020 \mathrm{mg} \mathrm{L}^{-1}$ aqueous solution of the dye or a $0.05 \mathrm{mg} \mathrm{L}^{-1}$ aqueous solution of potassium chromate and left still for $24 \mathrm{~h}$ at room temperature. Then, the solution was poured out and the absorbance (in the case of methyl orange) or the chromium content (in the case of potassium chromate) was measured and compared with that of the reference (Figure 6).

The results obtained (adsorption efficiencies $A E \% \approx 54 \%$ for acidic methyl orange and $A E \% \approx 71 \%$ for hexavalent chromium) are promising, especially considering the small amount of active material that decorates the bottle (ca. $1 \pm 0.1 \mathrm{mg} \mathrm{cm}^{-2}$, as determined by gravimetry) and that the solution was not stirred. To test the adherence of particles against mechanical stresses, the prototype was filled with water and manually shaken for $10 \mathrm{~min}$ : no significant detachment from the bottle walls could be noticed by eye inspection and no particles could be found in the water after centrifugation. 

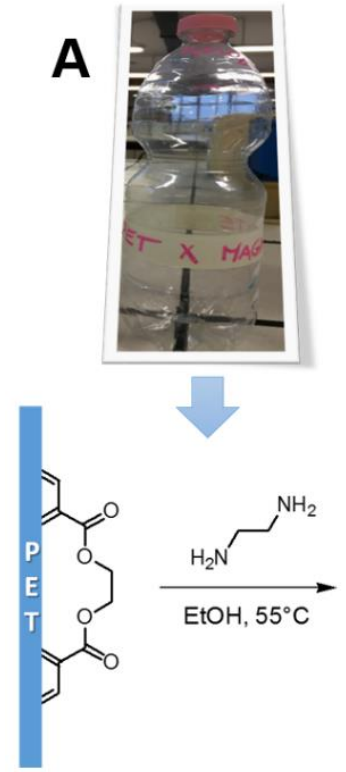
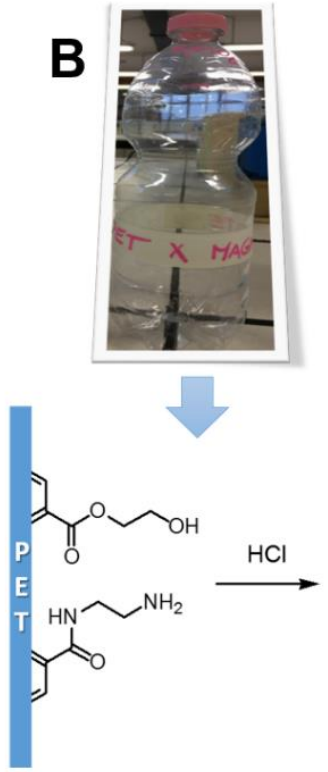
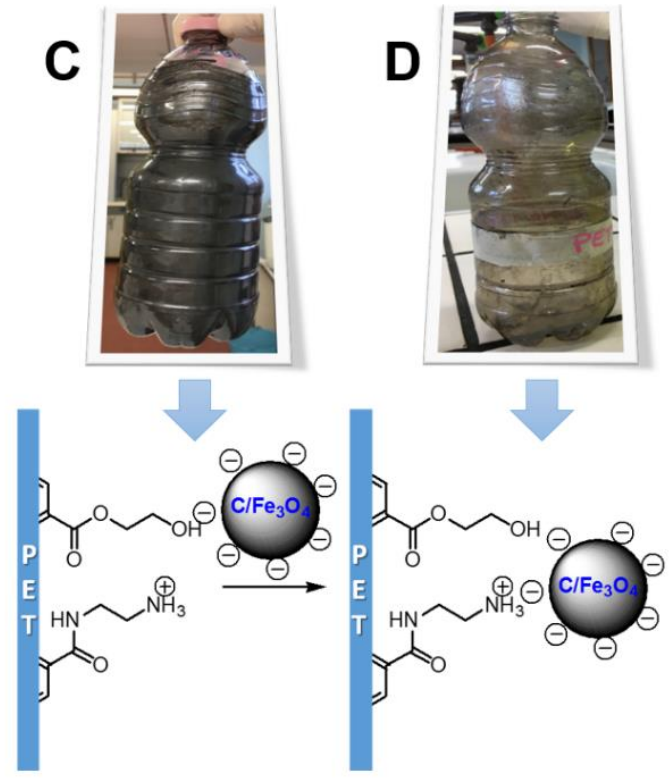

Figure 5. Schematic representation of the development of the purification device prototype. Pictures taken from each step are shown (see also Figure S5): (A,B) poly(ethylene terephthalate) (PET) bottle before and after aminolysis, (C) adhesion of magnetite-carbon composite particles (before rinsing), (D) the final prototype.
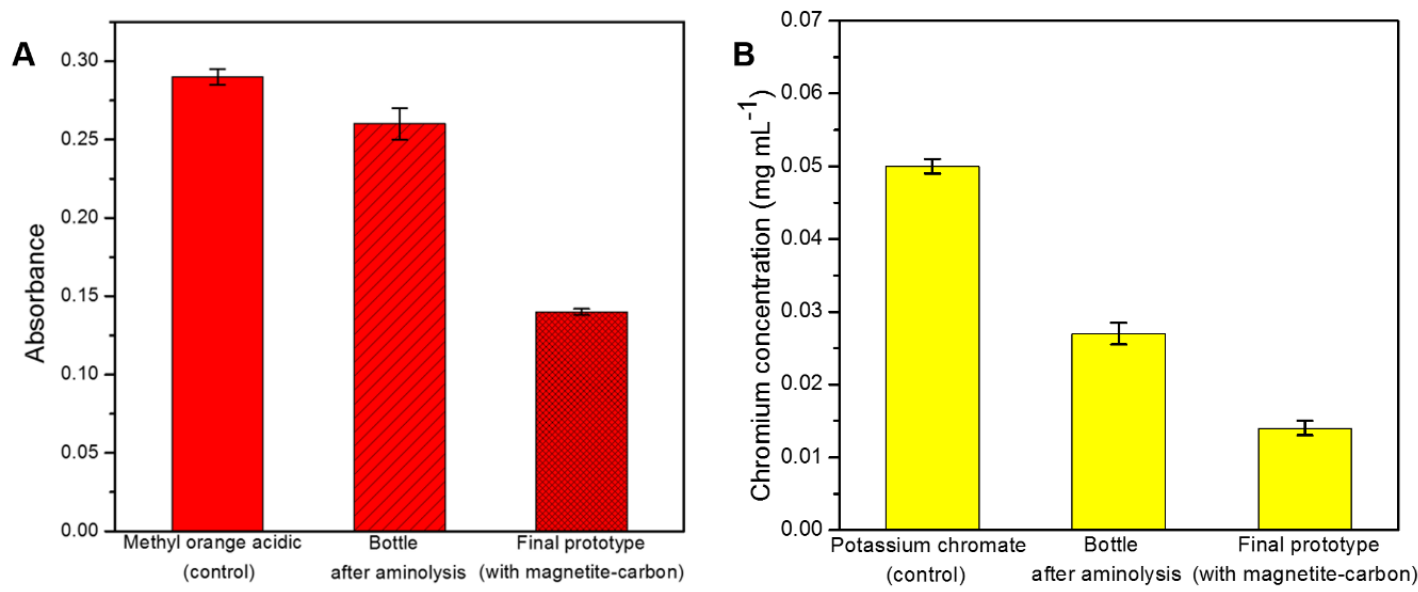

Figure 6. Efficacy of the modified bottle prototype for the removal of (A) acidic methyl orange and (B) hexavalent chromium from water. The data are the average of three measurements on three different prototypes.

\subsection{Challenges and Opportunities for Real-World Applications}

The main challenges that could be expected in translating our proof-of-concept approach into reality can be summarized as follows: (i) availability of PET bottles; (ii) availability of the necessary reagents; and (iii) existence of a market. Regarding point (i), given the success of SODIS practices (as explained in the Introduction), PET bottles are widely available in places such as India and Africa. Regarding point (ii), iron(II) and iron(III) salts (not necessarily chlorides) could be prepared from scrap iron and dilute acids (hydrochloric, sulfuric, and even acetic), ethanol could be easily produced by fermentation, and amines such as ethylenediamine are widely used in industrial processes. Regarding point (iii), i.e., the existence and/or generation of a market, this would depend mainly on political and entrepreneurship factors and it is thus difficult to estimate here. 
Cost is also a very important factor that needs to be taken into consideration. We estimated, for our prototype, an average cost of fabrication (based on current prices for the necessary reagents) of less than $0.5 €$ for a single device. Obviously, the price may be significantly lowered by using chemicals of purity lower than analytical grade and/or locally produced chemicals. Thus, its relatively low cost, coupled with the ease of fabrication and use, could make the proposed device competitive (even for single-use purposes) for medium- to large-scale production, especially in developing countries (i.e., where it would be required the most).

\section{Materials and Methods}

Iron(III) chloride, iron(II) chloride, concentrated ammonium hydroxide (28\%), concentrated hydrochloric acid (32\%), ethylenediamine, ethanol (anhydrous), activated carbon (puriss., p.a.), potassium chromate, methyl orange, and methylene blue were purchased from Sigma-Aldrich (Italy). All chemicals were of reagent or analytical purity and used as received.

\subsection{Synthesis of Magnetite Nanoparticles and of the Magnetite-Carbon Nanocomposite}

The synthesis of magnetite nanoparticles and of the magnetite-carbon nanocomposite was performed according to an established literature protocol [46]. Briefly, $1 \mathrm{~mL}$ of a $\mathrm{FeCl}_{2} 2 \mathrm{M}$ solution in $\mathrm{HCl} 2 \mathrm{M}$ and $4 \mathrm{~mL}$ of $\mathrm{FeCl}_{3} 1 \mathrm{M}$ solution in $\mathrm{HCl} 2 \mathrm{M}$ were stirred together in a beaker. Then, $50 \mathrm{~mL}$ of $\mathrm{NH}_{4} \mathrm{OH} 1.4 \mathrm{M}$ was added dropwise, generating a quick color change from light brown to black. The resulting magnetic particles were separated by magnetic decantation, washed many times with distilled water, and stored as aqueous suspension. For the preparation of the magnetite-carbon nanocomposite, the same procedure was followed but $0.10 \mathrm{~g}$ of activated carbon powder was added to the iron salts solution before the addition of ammonium hydroxide. The concentration of the obtained suspensions was determined gravimetrically.

\subsection{Preparation of the Portable Water Purification Device}

For the preparation of the portable water purification device, commercial poly(ethylene terephthalate) (PET) bottles were filled with a $40 \%(\mathrm{~V} / \mathrm{V})$ solution of ethylenediamine in ethanol and heated in a water bath at $55^{\circ} \mathrm{C}$ for $30 \mathrm{~min}$ [44]. The bottles were washed thoroughly first with deionized water to remove excess ethylenediamine, then with $10 \mathrm{~mL}$ of $\mathrm{HCl} 1 \mathrm{M}$ to ensure the complete protonation of amine groups, and eventually rinsed with water. Then, $10 \mathrm{~mL}$ of a concentrated suspension of the magnetite-carbon nanocomposite was poured into the bottles and homogeneously spread to cover its internal walls. After $10 \mathrm{~min}$, the excess of magnetite-activated carbon nanoparticles that were not adhering to the bottle walls was removed by gentle washing with water and the bottles were dried at room temperature.

\subsection{Characterization Techniques}

Transmission electron microscopy (TEM) was carried out with a Zeiss LIBRA 200FE (Carl Zeiss AG, Jena, Germany) equipped with a $200 \mathrm{kV}$ field emission gun (FEG). The samples were ultrasonically dispersed in isopropyl alcohol and a drop of the suspension was deposited on a holey carbon copper grid (300 mesh). X-ray powder diffraction (XRPD) was performed with a Philips PW 1820 diffractometer (Philips, Andover, MA, USA), using $\mathrm{Cu}-\mathrm{K} \alpha$ radiation, $40 \mathrm{kV}, 50 \mathrm{~mA}$. Zeta potential analyses were performed using a ZetaSizer APS Nano (Malvern Panalytical, London, UK) using $10 \mathrm{mM}$ $\mathrm{NaCl}$ as the supporting electrolyte. UV-visible spectrophotometry (UV-vis) was performed with a Cary 60 UV-vis spectrophotometer (Agilent, Santa Clara, CA, USA). Atomic absorption spectroscopy (AAS) was performed with a Perkin Elmer 1100B instrument (Perkin Elmer, San Francisco, CA, USA). 
Determination of Adsorption Efficiency for Hexavalent Chromium and Organic Dyes

To determine the adsorption efficiency $(A E \%)$, the concentration of pollutants before and after treatment with the synthesized materials was measured by means of $\mathrm{UV}-\mathrm{vis}\left(\mathrm{Cr}^{6+}\right.$ and dyes) and AAS (only $\mathrm{Cr}^{6+}$ ).

To perform UV-visible spectroscopy, $4 \mathrm{~mL}$ of the aqueous suspension of the material to be tested (corresponding to $0.24 \mathrm{~g}$ of solid) and $5 \mathrm{~mL}$ of deionized water were added in a test tube to $1 \mathrm{~mL}$ of a $10 \mathrm{mg} \mathrm{L}^{-1}$ potassium chromate or a $0.2 \mathrm{mg} \mathrm{L}^{-1}$ dye solution. For the test with acidic methyl orange, $50 \mu \mathrm{L}$ of $\mathrm{HCl} 1 \mathrm{M}$ was also added. The mixture was then stirred for $10 \mathrm{~min}$, the nanoparticles were removed through magnetic decantation, and the supernatant was analyzed. The light absorption at specific wavelengths ( $435 \mathrm{~nm}$ for chromate, $464 \mathrm{~nm}$ for methyl orange, $520 \mathrm{~nm}$ for acidic methyl orange, and $665 \mathrm{~nm}$ for methylene blue) of the references and of the treated solutions was then measured. The dye reference solutions were obtained by diluting $1 \mathrm{~mL}$ of each mother solution with $9 \mathrm{~mL}$ of water. From UV-vis data, $A E \%$ was calculated according to the following equation:

$$
A E \%=\frac{A b s_{0}-A b s}{A b s_{0}} \times 100
$$

where $A b s_{0}$ and $A b s$ are, respectively, the initial absorbance and the absorbance after treatment.

To perform atomic absorption spectroscopy (AAS), $4 \mathrm{~mL}$ of the aqueous suspension of the material to be tested (corresponding to $0.24 \mathrm{~g}$ of solid) and $5 \mathrm{~mL}$ of deionized water were added to $1 \mathrm{~mL}$ of a $26 \mathrm{mg} \mathrm{L}^{-1}$ potassium chromate in a test tube. The mixture was then stirred for $10 \mathrm{~min}$, the nanoparticles were removed through magnetic decantation, and the supernatant was analyzed. From AAS data, $A E \%$ was calculated according to the following equation:

$$
A E \%=\frac{c_{0}-c}{c_{0}} \times 100
$$

where $c_{0}$ and $c$ are, respectively, the initial concentration of chromium and the concentration after treatment.

\section{Conclusions}

PET bottles are widely available worldwide, even in developing and rural countries, where practices already exist involving their collection and re-use for solar water disinfection (SODIS) purposes. While allowing for the inactivation of pathogenic microorganisms, unfortunately, this technique is inefficient against chemical contaminants. The main goal of the present work was to demonstrate the possibility of re-using PET bottles as portable water purification devices based on a magnetite-carbon nanocomposite, allowing the removal of model inorganic and organic pollutants. The overall procedure is easy to follow, does not require access to specific materials and apparatuses, is affordable, and can be a fruitful starting point for the development of similar technologies.

Supplementary Materials: The following are available online at http://www.mdpi.com/2313-4321/3/3/31/s1: Figure S1: X-ray powder diffraction (XRPD) spectrum of magnetite nanoparticles. The peaks assigned to $\mathrm{Fe}_{3} \mathrm{O}_{4}$ are marked with red lines. Figure S2: Calibration lines for chromate by (A) UV-vis, (B) AAS. Figure S3: Pictures showing the appearance of dye solutions before and after treatment with the activated carbon-magnetite composite: (a) methyl orange, (b) methylene blue. Figure S4: Reproducibility test for the removal efficiency of the magnetite-carbon nanocomposite. The results are the average of three different measurements. Conditions: 0.05 $\mathrm{mg}$ of dye, $0.24 \mathrm{~g}$ of particles, $10 \mathrm{~mL}$ water, contact time $10 \mathrm{~min}$. Figure S5: A piece of the water purification device showing its transparency after aminolysis and decoration with the magnetite-activated carbon nanocomposite. The picture also demonstrates that the nanocomposite is evenly distributed on the plastic surface.

Author Contributions: E.G. performed the experimental work. C.E. performed TEM analysis. G.P. conceived and designed the experiments, supervised the work, analyzed the data, and wrote the manuscript. 
Acknowledgments: Enrico Caprioglio, Alessandro Coppa, and Riccardo Roggero are kindly acknowledged for their contributions. Gianluigi Marra (Eni Donegani Research Center for Renewable Energies and the Environment, Novara, Italy) is kindly acknowledged for performing the XRPD analysis. This research did not receive any specific grant from funding agencies in the public, commercial, or not-for-profit sectors.

Conflicts of Interest: The authors declare no conflict of interest.

\section{References}

1. Moe, C.L.; Rheingans, R.D. Global challenges in water, sanitation and health. J. Water Health 2006, 4, 41-58. [CrossRef] [PubMed]

2. Ahmed, T.; Imdad, S.; Yaldram, K.; Butt, N.M.; Pervez, A. Emerging nanotechnology-based methods for water purification: A review. Desalin. Water Treat. 2014, 52, 4089-4101. [CrossRef]

3. Kwon, J.H.; Wilson, L.D.; Sammynaiken, R. Synthesis and characterization of magnetite and activated carbon binary composites. Synth. Met. 2014, 197, 8-17. [CrossRef]

4. Linley, S.; Leshuk, T.; Gu, F.X. Magnetically separable water treatment technologies and their role in future advanced water treatment: A patent review. Clean Soil Air Water 2013, 41, 1152-1156. [CrossRef]

5. Oliveira, L.C.A.; Rios, R.V.R.A.; Fabris, J.D.; Garg, V.; Sapag, K.; Lago, R.M. Activated carbon/iron oxide magnetic composites for the adsorption of contaminants in water. Carbon N. Y. 2002, 40, 2177-2183. [CrossRef]

6. Ma, J.; Sun, S.; Chen, K. Facile and scalable synthesis of magnetite/carbon adsorbents by recycling discarded fruit peels and their potential usage in water treatment. Bioresour. Technol. 2017, 233, 110-115. [CrossRef] [PubMed]

7. Welle, F. Twenty years of PET bottle to bottle recycling-An overview. Resour. Conserv. Recycl. 2011. [CrossRef]

8. Mancini, S.D.; Schwartzman, J.A.S.; Nogueira, A.R.; Kagohara, D.A.; Zanin, M. Additional steps in mechanical recyling of PET. J. Clean. Prod. 2010. [CrossRef]

9. Nakatani, J.; Fujii, M.; Moriguchi, Y.; Hirao, M. Life-cycle assessment of domestic and transboundary recycling of post-consumer PET bottles. Int. J. Life Cycle Assess. 2010. [CrossRef]

10. Zhang, H.; Wen, Z.G. The consumption and recycling collection system of PET bottles: A case study of Beijing, China. Waste Manag. 2014. [CrossRef] [PubMed]

11. Conroy, R.M.; Meegan, M.E.; Joyce, T.; McGuigan, K.; Barnes, J. Solar disinfection of drinking water protects against cholera in children under 6 years of age. Arch. Dis. Child. 2001. [CrossRef]

12. Mäusezahl, D.; Christen, A.; Pacheco, G.D.; Tellez, F.A.; Iriarte, M.; Zapata, M.E.; Cevallos, M.; Hattendorf, J.; Cattaneo, M.D.; Arnold, B.; Smith, T.A.; Colford, J.M. Solar drinking water disinfection (SODIS) to reduce childhood diarrhoea in rural Bolivia: A cluster-randomized, controlled trial. PLoS Med. 2009. [CrossRef] [PubMed]

13. Conroy, R.M.; Elmore-Meegan, M.; Joyce, T.; McGuigan, K.G.; Barnes, J. Solar disinfection of drinking water and diarrhoea in Maasai children: A controlled field trial. Lancet 1996. [CrossRef]

14. Caslake, L.F.; Connolly, D.J.; Menon, V.; Duncanson, C.M.; Rojas, R.; Tavakoli, J. Disinfection of Contaminated Water by Using Solar Irradiation. Appl. Environ. Microbiol. 2004. [CrossRef]

15. Acher, A.; Fischer, E.; Turnheim, R.; Manor, Y. Ecologically friendly wastewater disinfection techniques. Water Res. 1997. [CrossRef]

16. Ciochetti, D.A.; Metcalf, R.H. Pasteurization of naturally contaminated water with solar energy. Appl. Environ. Microbiol. 1984.

17. Burch, J.D.; Thomas, K.E. Water disinfection for developing countries and potential for solar thermal pasteurization. Sol. Energy 1998. [CrossRef]

18. Hillie, T.; Hlophe, M. Nanotechnology and the challenge of clean water. Nat. Nanotechnol. 2007, 2, 663-664. [CrossRef] [PubMed]

19. Holkar, C.R.; Jadhav, A.J.; Pinjari, D.V.; Mahamuni, N.M.; Pandit, A.B. A critical review on textile wastewater treatments: Possible approaches. J. Environ. Manag. 2016, 182, 351-366. [CrossRef] [PubMed]

20. Lofrano, G.; Carotenuto, M.; Libralato, G.; Domingos, R.F.; Markus, A.; Dini, L.; Gautam, R.K.; Baldantoni, D.; Rossi, M.; Sharma, S.K.; Chattopadhyaya, M.C.; Giugni, M.; Meric, S. Polymer functionalized nanocomposites for metals removal from water and wastewater: An overview. Water Res. 2016, 92, 22-37. [CrossRef] [PubMed] 
21. Oller, I.; Malato, S.; Sánchez-Pérez, J.A. Combination of Advanced Oxidation Processes and biological treatments for wastewater decontamination-A review. Sci. Total Environ. 2011, 409, 4141-4166. [CrossRef] [PubMed]

22. Su, C.X.H.; Low, L.W.; Teng, T.T.; Wong, Y.S. Combination and hybridisation of treatments in dye wastewater treatment: A review. J. Environ. Chem. Eng. 2016, 4, 3618-3631. [CrossRef]

23. Liu, Y.; Li, F.; Xia, Q.; Wu, J.; Liu, J.; Huang, M.; Xie, J. Conductive 3D Sponge for Affordable and Highly-efficient Water Purification. Nanoscale 2018. [CrossRef] [PubMed]

24. Panzarasa, G.; Osypova, A.; Consolati, G.; Quasso, F.; Soliveri, G.; Ribera, J.; Schwarze, F.W.M.R. Preparation of a sepia melanin and poly(ethylene-alt-maleic anhydride) hybrid material as an adsorbent for water purification. Nanomaterials 2018, 8, 54. [CrossRef] [PubMed]

25. Sun, S.; Zeng, H. Size-controlled synthesis of magnetite nanoparticles. J. Am. Chem. Soc. 2002. [CrossRef]

26. Mirabello, G.; Lenders, J.J.M.; Sommerdijk, N.A.J.M. Bioinspired synthesis of magnetite nanoparticles. Chem. Soc. Rev. 2016. [CrossRef] [PubMed]

27. Schladt, T.D.; Schneider, K.; Schild, H.; Tremel, W. Synthesis and bio-functionalization of magnetic nanoparticles for medical diagnosis and treatment. Dalt. Trans. 2011, 40, 6315. [CrossRef] [PubMed]

28. Revia, R.A.; Zhang, M. Magnetite nanoparticles for cancer diagnosis, treatment, and treatment monitoring: Recent advances. Mater. Today 2016, 19, 157-168. [CrossRef] [PubMed]

29. Schleich, N.; Danhier, F.; Préat, V. Iron oxide-loaded nanotheranostics: Major obstacles to in vivo studies and clinical translation. J. Control. Release 2015, 198, 35-54. [CrossRef] [PubMed]

30. Stephen, Z.R.; Kievit, F.M.; Zhang, M. Magnetite nanoparticles for medical MR imaging. Mater. Today 2011, 14, 330-338. [CrossRef]

31. Lattuada, M.; Ren, Q.; Zuber, F.; Galli, M.; Bohmer, N.; Matter, M.T.; Wichser, A.; Bertazzo, S.; Pier, G.B.; Herrmann, I.K. Theranostic body fluid cleansing: Rationally designed magnetic particles enable capturing and detection of bacterial pathogens. J. Mater. Chem. B 2016, 4, 7080-7086. [CrossRef]

32. McCloskey, K.E.; Chalmers, J.J.; Zborowski, M. Magnetic Cell Separation: Characterization of Magnetophoretic Mobility. Anal. Chem. 2003, 75, 6868-6874. [CrossRef] [PubMed]

33. Ambashta, R.D.; Sillanpää, M. Water purification using magnetic assistance: A review. J. Hazard. Mater. 2010, 180, 38-49. [CrossRef] [PubMed]

34. Xu, P.; Zeng, G.M.; Huang, D.L.; Feng, C.L.; Hu, S.; Zhao, M.H.; Lai, C.; Wei, Z.; Huang, C.; Xie, G.X.; Liu, Z.F. Use of iron oxide nanomaterials in wastewater treatment: A review. Sci. Total Environ. 2012, 424, 1-10. [CrossRef] [PubMed]

35. Pang, S.C.; Chin, S.F.; Anderson, M.A. Redox equilibria of iron oxides in aqueous-based magnetite dispersions: Effect of $\mathrm{pH}$ and redox potential. J. Colloid Interface Sci. 2007, 311, 94-101. [CrossRef] [PubMed]

36. Salazar-Camacho, C.; Villalobos, M.; de la Luz Rivas-Sánchez, M.; Arenas-Alatorre, J.; Alcaraz-Cienfuegos, J.; Gutiérrez-Ruiz, M.E. Characterization and surface reactivity of natural and synthetic magnetites. Chem. Geol. 2013, 347, 233-245. [CrossRef]

37. Gupta, V.K. Suhas Application of low-cost adsorbents for dye removal-A review. J. Environ. Manag. 2009, 90, 2313-2342. [CrossRef] [PubMed]

38. Ahn, T.; Kim, J.H.; Yang, H.M.; Lee, J.W.; Kim, J.D. Formation pathways of magnetite nanoparticles by coprecipitation method. J. Phys. Chem. C 2012, 116, 6069-6076. [CrossRef]

39. Sun, Z.X.; Su, F.W.; Forsling, W.; Samskog, P.O. Surface characteristics of magnetite in aqueous suspension. J. Colloid Interface Sci. 1998, 197, 151-159. [CrossRef] [PubMed]

40. Sedman, R.M.; Beaumont, J.; McDonald, T.A.; Reynolds, S.; Krowech, G.; Howd, R. Review of the evidence regarding the carcinogenicity of hexavalent chromium in drinking water. J. Environ. Sci. Health C. Environ. Carcinog. Ecotoxicol. Rev. 2006, 24, 155-182. [CrossRef] [PubMed]

41. Dai, M. Mechanism of Adsorption for Dyes on Activated Carbon. J. Colloid Interface Sci. 1998, 198, 6-10. [CrossRef]

42. Ravindranath, K.; Mashelkar, R.A. Polyethylene terephtalate-II. Engineering analysis. Chem. Eng. Sci. 1986, 41, 2969-2987. [CrossRef]

43. Lepoittevin, B.; Costa, L.; Pardoue, S.; Dragoé, D.; Mazerat, S.; Roger, P. Hydrophilic PET surfaces by aminolysis and glycopolymer brushes chemistry. J. Polym. Sci. Part A Polym. Chem. 2016, 54, 2689-2697. [CrossRef] 
44. Noel, S.; Liberelle, B.; Robitaille, L.; De Crescenzo, G. Quantification of primary amine groups available for subsequent biofunctionalization of polymer surfaces. Bioconjug. Chem. 2011, 22, 1690-1699. [CrossRef] [PubMed]

45. Bech, L.; Meylheuc, T.; Lepoittevin, B.; Roger, P. Chemical surface modification of poly(ethylene terephthalate) fibers by aminolysis and grafting of carbohydrates. J. Polym. Sci. Part A Polym. Chem. 2007, 45, 2172-2183. [CrossRef]

46. Furlan, P.Y.; Melcer, M.E. Removal of aromatic pollutant surrogate from water by recyclable magnetite-activated carbon nanocomposite: An experiment for general chemistry. J. Chem. Educ. 2014, 91, 1966-1970. [CrossRef]

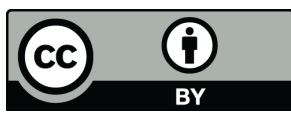

(C) 2018 by the authors. Licensee MDPI, Basel, Switzerland. This article is an open access article distributed under the terms and conditions of the Creative Commons Attribution (CC BY) license (http:/ / creativecommons.org/licenses/by/4.0/). 